Усе це вимагає спеціальної професійної і організаційної допомоги, спрямованої на взаєморозуміння і продуктивну взаємодію представників різних спеціальностей, що беруть участь у процесі соціалізації дитини.

Отже, професійні знання педагогів про роль соціального середовища у вихованні та соціалізації особистості актуалізують проблему ціннісних характеристик соціуму, у якому розгортається діяльність групи, дошкільної установи і окремої дитини. Педагог сприяє «розпредмеченню» середовища, розширюючи, збагачуючи його не лише соціальними стосунками, але й переводячи предметно-речове облаштування життєдіяльності дитини в соціальний контекст. Конструювання дитиною образу соціального світу, який постає перед нею як певна соціальна реальність, вимагає соціально-педагогічного супроводу соціалізації особистості дитини, що передбачає врахування та вивчення всієї повноти іiі взаємодії з соціальним середовищем, зі світом людей, різними соціальними інститутами мікросоціуму для забезпечення гармонійної соціалізації особистості. Педагогічне осмислення того, що активне пізнання соціальної реальності, у якій живе дитина, і $€$ важливою умовою для формування адекватного образу соціального світу.

\title{
Література
}

1. Асмолов О. Главное - сохранить почемучек / О. Асмолов // Дошкольное воспитание. -2005. - № 3. - С. 68-69. 2. Богуш А. М. Дитинство: погляд сьогодення / А.М. Богуш // Виховання і культура. - 2003. - № 1-2. - С. 4-10. 3. Детский сад вчера, сегодня, завтра // Дошкольное воспитание. - 2005. - № 8. - С. 88-95. 4. Ніколаєнко С. Якісна освіта - запорука реалізації особистості / С. Ніколаєнко // Дошкільне виховання. - 2007. - № 9. - С. 3-6. 5. Хоментаускас Г. Т. Семья глазами ребенка / Г. Т. Хоментаускас. - М. : Педагогика, 1989. - 154 с. 6. Щербак Н. Д. Соціально-педагогічна профілактика жорстокого ставлення до дітей у сім'ї: автореф. дис. на здобуття наук. ступеня канд. пед. наук: спец. 13.00 .05 - соціальна педагогіка / Н. Д. Щербак. Луганськ, 2004. - 20 с.

УДК $373.2(07)$

К. С. Суятинова, асистент,

Криворізький педагогічний інститут ДВНЗ «Криворізький національний університет»

\section{УМОВИ ЗАБЕЗПЕЧЕННЯ РІВНИХ СТАРТОВИХ МОЖЛИВОСТЕЙ ЗДОБУТТЯ ПЕРЕДШКІЛЬНОЇ ОСВІТИ}

Суятинова К. Є. Умови забезпечення рівних стартових можливостей здобуття передшкільної освіти.

У статті розглянуто проблему наступності та безперервності освіти в Україні, здійснено огляд організаційних форм здобуття передшкільної освіти для дітей п'ятирічного віку, які не відвідують дошкільних закладів. Подано досвід роботи колективу закладу, на базі якого створено канікулярно-адаптаційну групу та роботу консультативного пункту.

Ключові слова: передшкільна освіта, безперервна освіта, наступність у навчанні, форми здобуття передшкільної освіти дітей, організація роботи з дітьми п’ятирічного віку.

Суятинова Е. Е. Условия обеспечения равных стартовых возможностей получения образования старшими дошкольниками.

В статье рассмотрена проблема преемственности и непрерывности образования в Украине, дан обзор поисков эффективных организационных подходов к созданию новых форм дошкольного образования для детей, не охваченных дошкольным воспитанием. Представлен опыт работы с детьми пятилетнего возраста на базе детского сада.

Ключевые слова: предшкольная подготовка, непрерывное образование, преемственность, формы получения дошкольного образования, организация работы с детьми пятилетнего возраста.

Suyatinova K. E. Terms of providing of equal starting possibilities of receipt of pre-school education. 
In the article an author examines the problem of the following and continuity of education in Ukraine, gives the review of organizational forms of receipt of pre-school education for the children of five-year age, which do not visit preschool establishments. Presents experience collective of establishment, on the base of which it is created kanikulyarno adaptation group and work of konsul'tativnogo point.

Key words: pre-school preparation, continuous education, succession, forms of preschool education, organization of raboti with the children of five-year age.

Закон України «Про дошкільну освіту» визначив дошкільну освіту як обов'язковий первинний складник системи безперервної освіти в Україні, що забезпечує різнобічний розвиток дитини відповідно до ії задатків, нахилів, індивідуальних, психічних та фізичних особливостей, культурних потреб (ст. 2).

Потреби суспільства спонукали до внесення змін до Закону України «Про дошкільну освіту» щодо обов'язковості здобуття дітьми п'ятирічного віку дошкільної освіти. Проте обов'язковість дошкільної освіти не означає, що діти повинні перебувати в дошкільному навчальному закладі щодня та протягом дня. Батьки мають змогу обирати різні форми здобуття дітьми дошкільної освіти (ст. 9).

Проблема наступності між дошкільною та початковою ланками освіти й нині залишається актуальною. Проблема пошуку ефективного здійснення наступності дошкільної та початкової освіти перебувала і залишається в центрі уваги психологопедагогічної науки і практики. Забезпечення наступності між дошкіллям та школою спільне завдання вихователів, учителів, батьків, здійснювати яке вони мають разом, ураховуючи педагогічний вплив одне одного й висуваючи до дітей єдині вимоги. «Відповідно до чинного законодавства та нормативно-правових документів саме наступність $є$ однією з обов'язкових умов здійснення неперервності здобуття освіти, яка певною мірою має забезпечити єдність, взаємозв'язок та узгодженість мети, змісту, методів, форм навчання й виховання 3 урахуванням вікових особливостей дітей на суміжних щаблях освіти» $[1$, с. 4$]$.

Перехід дошкільника від дитячого садочка до школи становить переломний етап у його житті, формуванні його особистості. Російські дослідники О. Тихєєва, Р. Буре, Г. Петроченко, Ш. Амонашвілі, Л. Виготський, Л. Журова зауважували, що з переходом до систематичного навчання у школі завершується дошкільне дитинство і починається період шкільного життя. Змінюється образ життя дитини, встановлюється нова система відносин 3 довкіллям, складаються нові форми діяльності. Про значимість і складність періоду переходу дошкільника до школи говорили Л. Божович, Л. Венгер, В. Холмовський, І. Дубровіна. Науковці стверджують про взаємозв'язок між роботою по здійсненню наступності та рівнем готовності дітей до школи.

Актуальність проблеми пояснюється необхідністю створити сприятливі умови для переходу дитини від однієї освітньої ланки до іншої.

У 2000 році за сприяння Міністерства освіти і науки України та Академії педагогічних наук на базі Переяслав-Хмельницького державного педінституту ім. Г.Сковороди було проведено Міжнародну науково-практичну конференцію, на якій особливу увагу було приділено доповіді віце-президента АПН України, академіка, доктора педагогічних наук О. Савченко. Принцип наступності науковець розглядає у безпосередньому взаємозв'язку 3 принципом перспективності. Дослідниця підкреслює, що вчителі-початківці мають учитися в дошкільників: «В основі нової орієнтації педагогічної системи лежить глибоке знання дитини, і якщо педагоги-дошкільники в цьому досить обізнані, то вчителів початкових класів треба ще багато чого навчати, переконувати їх у перевагах змістовного психологічного вивчення кожного учня» [5, с. 5]. О. Савченко стверджує, що «в початковій школі маємо створювати такі умови, щоб ті якості, уміння, здобутки дошкілля, формування яких ще не завершилося на рівні дошкільного віку, могли б повноцінно розвиватися в початковій школі» $[5$, с. 5].

Уперше проблему розроблення передшкільної освіти було проголошено на міжнародній конференції «Передшкільна освіта: проблеми та перспективи» (2008), що відбулася в Миколаєві (на базі Миколаївського державного університету імені В. О. Сухомлинського). 
Аналіз вітчизняного досвіду передшкільної освіти дозволив виокремити в якості основної характеристики підхід, орієнтований на підготовку дітей до навчання у школі. Уперше спробу підготувати дітей до школи було здійснено ще на початку XX століття у великих містах України. Саме тоді було проведено експеримент по введенню ігор до навчального процесу першокласників із метою збереження наступності 3 дитячим садком. Пізніше відомі психологи Л. Венгер, О. Запорожець, Д. Ельконін та ін. у своїх працях обгрунтували функції і структури передшкільної освіти.

Варто зауважити, що МОНмолодьспорту України та Інститут інноваційних технологій чітко й оперативно прописали нормативно-правове та методичне забезпечення супроводу дітей старшого дошкільного віку. Більше 20 найменувань нормативно-правових актів, листів, наказів, рекомендацій нині регламентують функціонування ДНЗ та груп дітей п’ятирічного віку. Цими та іншими нормативними документами держава гарантує право дитини на доступність і безоплатність здобуття дошкільної освіти.

Поняття «наступність у навчанні» вперше отримало теоретичне обгрунтування в працях Е. Баллера, Г. Ісаєнка, ставши згодом предметом багатьох досліджень у вітчизняній і зарубіжній педагогіці.

Необхідність дотримання наступності в роботі з дошкільниками обгрунтовували у своїх працях Л. Артемова, О. Богданович, А. Богуш, В. Борисова, Л. Божович, Т. Дябло, Л. Іщенко, Л. Калмикова, О. Киричук, Я. Коменський, В. Кузь, М. Кухта, В. Ликова, Г. Люблінська, Г. Назаренко, О. Проскура, Й.-Г.Песталоцці, С. Рубінштейн, С. Русова, О. Савченко, О. Усова, К. Ушинський та ін.

Як стверджує Г. Назаренко, «проблема наступності має комплексний i міждисциплінарний характер, перебуваючи на перетині проблемних сфер педагогіки, психології, філософії, соціології, фізіології. Тому іiі сучасний стан характеризується різнобічністю охоплення багатьох питань та неоднозначністю їх трактування» [3, с.1].

Дослідженню питання організаційних форм роботи 3 дітьми, які не відвідують дошкільних закладів, приділяли увагу такі науковці, як Н. Бабій, Н. Гагаріна, О. Долинна, Л. Зданевич, Н. Козак, О. Кононко, В. Кузь, Н. Курочка, С. Палець, В. Палійчук, А. Середницька, Н. Тарапака.

Основна мета передшкільної освіти - створити рівні стартові можливості для дітей, які мають різнорівневу підготовку, а також формування фізичної, особистісної, інтелектуальної і соціальної готовності дітей до навчання в школі; розробити технологію й інструментальні засоби для впровадження цієї програми в педагогічну практику дошкільного закладу та початкової школи. Формами здобуття передшкільної освіти для дітей п'ятирічного віку можуть бути: 1) групи короткотривалого перебування дітей в дошкільних закладах; 2) підготовчі класи в навчально-виховному комплексі «Школа - дошкільний навчальний заклад»; 3) підготовка дітей до школи в домашніх умовах під патронажем відділу освіти; 4) корекційні групи в дошкільних закладах освіти (надання сучасної систематичної психологомедико-педагогічної допомоги дітям, в тому числі і дітям, які мають проблеми у фізичному і психічному розвитку); 5) консультативні пункти для батьків (надання допомоги батькам під час підготовки дітей до школи); 6) центри розвитку дитини.

Mета статmi - на основі аналізу законодавчої бази, навчально-методичної літератури та матеріалів періодики вивчити й узагальнити умови, які б забезпечували наступність у навчанні дітей старшого дошкільного віку, а також надавали рівних стартових можливостей у навчально-виховному процесі дітям старшого дошкільного віку, які відвідують дошкільні навчальні заклади та не відвідують їх.

Головною умовою забезпечення наступності у вихованні і навчанні $€$ спрямованість педагогічного процесу дошкільного навчального закладу і початкової школи на всебічний розвиток особистості. 3 огляду на це є необхідним взаємозв'язок програм, методів і форм навчання в дошкільному навчальному закладі та початковій школі [1, с. 4]. Сучасне бачення розв'язання проблеми, згідно з інструктивно-методичним листом полягає у створенні умов для реалізації в освітньому процесі дошкільних і загальноосвітніх 
навчальних закладів єдиної, динамічної, перспективної системи особистісного творчого зростання дитини.

Наступність виявляє себе у змісті, формах та методах роботи у старшій групі дошкільного навчального закладу та першому класі школи, які мають бути узгодженими між собою. Перспективність дозволяє бачити стратегію розвитку в майбутньому, прагнути створити кожній дитині у школі можливість реалізації ії здібностей. Спадкоємність - це безконфліктний, комфортний спосіб переходу дитини на новий для неї щабель [4, с. 12].

Отже, «наступність», «перспективність» і «спадкоємність» - це педагогічні аспекти неперервності освіти і підготовки дітей дошкільної ланки до навчання в початковій школі.

А. Курчатова, С. Мєдвєдєва стверджують, що основне педагогічне завдання дорослих «створити умови для повноцінного життя дошкільника, реалізації ним свого природного потенціалу (фізичного, психологічного, соціального), прояву індивідуальності [2, с. 23].

О. Савченко слушно зазначає: «Початкова школа, зберігаючи наступність із дошкільним періодом дитинства, протягом чотирьох років в умовах цілеспрямованого навчання i виховання забезпечує подальше становлення особистості дитини, iї інтелектуальний, фізичний, морально-етичний, мовленнєвий, естетичний, соціальний, емоційно-вольовий розвиток».

Проблема надання рівних стартових можливостей дошкільникам-п'ятирічкам спонукає педагогів усвідомити необхідність створення необхідних форм здобуття передшкільної освіти для забезпечення вчасного і повного фізичного, інтелектуального, морального, естетичного і соціального розвитку дітей дошкільного віку відповідно до задатків, нахилів, здібностей, індивідуальних особливостей. На допомогу вихователям стає Базова програма розвитку дитини дошкільного віку «Я у Світі» та програма розвитку дітей старшого дошкільного віку «Упевнений старт», Базовий компонент дошкільної освіти.

У досвідах роботи дошкільних навчальних закладів та початкових класах поступово формується єдине навчально-виховне середовище. Для цього організовуються зустрічі вчителів початкових класів з групами у дитячому садку; проводяться спільні заходи (свято Першого та Останнього дзвоника, Свято букваря), організовуються концерти, спортивні змагання; проводяться екскурсії для дітей старшого дошкільного віку до приміщень класу, шкільної бібліотеки; вчителі та вихователі проводять спільні педагогічні ради, наради, засідання методичних об'єднань, виставки, конференції; проводяться батьківські збори, консультації; організовуються взаємовідвідування занять і уроків вихователями та вчителями; обмін передовим педагогічним досвідом.

Так, наприклад, у КДНЗ № 123 загального розвитку щороку організовується та проводиться облік дітей старшого дошкільного віку, що не охоплені суспільним дошкільним вихованням; складається та затверджується план роботи з визначеної форми охоплення неорганізованих дітей дошкільною освітою. Так, у 2010-2011н. р. колективом КДНЗ № 123 було розроблено списки охоплення дітей дошкільною освітою від народження до 6 років та списки дітей неохоплених дошкільною освітою у своєму мікрорайоні. За цими списками 97,4 \% дітей 5-тирічного віку відвідували ДН3, 2,6 \% - не відвідували ДНЗ. У 2011-2012 н. р. кількість охоплених освітою дітей мікрорайону становила - 92,3 \%, не охоплених - 7,7 \%. У 2012-2013 н.р. кількість охоплених освітою дітей мікрорайону становила - 92,6\%, неохоплених - 7,4\%. Соціально-педагогічний патронат таких сімей здійснюється за місцем їх проживання вихователями ДНЗ.

3 дітьми п'ятирічного віку в ДНЗ проводиться робота практичним психологом по виявленню та направленню дітей на обстеження психолого-медико-педагогічною консультацією для визначення закладу подальшого навчання неохоплених старших дошкільників, проводять вхідне діагностування, вихідне діагностування стану підготовки до школи старших дошкільників, корекційну роботу.

На базі КДНЗ педагоги закладу розпочали роботу по створенню канікулярноадаптаційної групи, в якій діти мають можливість поспілкуватись 3 однолітками, взяти участь у святах, розвагах, конкурсах, лялькових виставах, тематичних розвагах, 
прогулянках, екскурсіях тощо. Для батьків колективом закладу проводяться батьківські збори, круглі столи, анкетування, індивідуальне консультування, Дні відкритих дверей, організовуються спільні свята і спортивні розваги, конкурси, створено консультативний пункт. Тематика зустрічей найрізноманітніша, наприклад, «Дитячий куточок вдома», «У центрі уваги - особистість», «Адаптація дітей у колективі», «Дитячі страхи: причини та наслідки», «Фізичне виховання в сім'ї», «Розуміємо ми дитину?», «Місце батька у вихованні дитини», «Готовність до навчання у школі». Працює консультативний пункт відповідно до складеного графіка роботи чотири рази на тиждень, індивідуальні консультації батьки можуть отримати за потребою у зручний для них час. Консультування батьків або осіб, які їх замінюють, може проводитись одним або декількома спеціалістами одночасно. Консультують батьків за попередньо складеним планом, який передбачає проведення організаційно-педагогічної роботи, методичної роботи, забезпечую дотримання зовнішніх зв'язків із психологічною службою, взаємодію зі школою, медичною службою тощо. Фіксація діяльності здійснюється у журналі звернень батьків.

Водночас, практика свідчить про те, що контакт між вихователями дошкільних навчальних закладів та вчителями початкових класів $є$ недостатнім, поверховим, іноді формальним. Важливим завданням на сучасному етапі є створення інформаційного поля із забезпечення та досягнення наступності етапів освіти. Сучасний дошкільний навчальний заклад освіти за умов оптимального використання його можливостей може розв'язати проблеми сучасної підготовки п'ятирічок до шкільного навчання за режимом та в обсязі, якій найбільше влаштовує і дитину, i батьків. Щоб забезпечити реальну перспективність $\mathrm{i}$ наступність у роботі дошкільної та початкової ланок освіти, надати дітям, які відвідують ДНЗ та не відвідують їх, рівних стартових можливостей здобуття передшкільної освіти, важливо дотримуватись певних умов: співробітництво має бути довготривалим i нерозривним, робота - системною і плановою, завдання - комплексним та інтегрованим.

\section{Література}

1. Інструктивно-методичні рекомендації «Про забезпечення взаємодії в освітній роботі з дітьми старшого дошкільного і молодшого шкільного віку» (Лист МОНмолодьспорту України від 19.08.2011 р. № 1/9-634) // Дошкільне виховання. - 2011. - № 9. - С.4-6. 2. Крайнова Л. До проблем наступності між дошкільним навчальним закладом і школою / Л. Крайнова // Дошкільна освіта. - 2010. - № 1. - С. 11-17. 3. Курчатова А. Скоро до школи. Забезпечення наступності між дошкільною та початковою освітою / А. Курчатова, С. Медвєдєва // Дошкільне виховання. - 2012. - № 8. - С.23-24. 4. Назаренко Г. І. Організаційно-педагогічні умови забезпечення наступності в навчанні дітей дошкільного та молодшого шкільного віку: автореф. дис. на здобуття наукового ступеня канд. пед. наук: спец. 12.00 .09 «Теорія навчання» / Г. І. Назаренко. - Кривий Ріг, 2002. 20 с. 5. Савченко О. Я. Наступність і перспектива в роботі двох перших ланок освіти / О. Я. Савченко // Дошкільне виховання. - 2000. - №11. - С. 4-5.

УДК 378.6.091.2:37

Я. В. Топольник, кандидат пед. наук, ст. викладач, Донбаський державний педагогічний університет

\section{ВИВЧЕННЯ СПЕЦКУРСУ «ОСНОВИ НАУКОВОЇ ОРГАНІЗАЦІЇ НАВЧАЛЬНОЇ ПРАЦІ СТУДЕНТІВ» ЯК УМОВА ЕФЕКТИВНОСТІ НАВЧАЛЬНОГО ПРОЦЕСУ}

Топольник Я. В. Вивчення спецкурсу «Основи наукової організації навчальної праці студентів» як умова ефективності навчального процесу.

У статті розглянуто аспекти проблеми наукової організації навчальної праці студентів педагогічного ВНЗ. Зазначено, що вимоги НОП охоплюють усі сторони життя студентів як у сфері навчально-пізнавальної діяльності, так і у сфері вільного часу. Доведено, що майбутні вчителі повинні оволодіти основами наукової організації педагогічної праці, уміннями НОП школярів. Звертається увага на те, що кращого результату навчання можна досягти за умови поєднання спеціального курсу щодо формування навчальних умінь 3 викладанням конкретних предметів психолого-педагогічного циклу. Подаються основні положення програми розробленого автором 